\title{
Comparative Studies on Egyptian and Libyan Roselle Seeds as a Source of Lipid and Protein
}

\author{
Nady A. Elneairy \\ Department of Food Science and Technology, Faculty of Agriculture, Fayoum University, Al Fayoum, Egypt \\ Email: nadyelneairy@yahoo.com
}

Received 25 October 2014; revised 27 November 2014; accepted 11 December 2014

Copyright (C 2014 by author and Scientific Research Publishing Inc.

This work is licensed under the Creative Commons Attribution International License (CC BY). http://creativecommons.org/licenses/by/4.0/

(c) (i) Open Access

\begin{abstract}
Proceeding from the fact that the seeds of Roselle plant are full of nutritional constituents, however in Egypt and Libya, they are often discarded as a by-product, this study aims to evaluate the nutritional composition of Roselle seeds grown in Egypt and Libya as a source of oil and protein besides making a comparison between whole chemical composition of Roselle seeds grown in both countries. Ground of whole Egyptian and Libyan Roselle seeds powder contained high amount of protein $(31.02 \% \pm 0.93 \%$ and $28.67 \% \pm 0.45 \%)$, crude fat $(21.6 \% \pm 0.66 \%$ and $16.94 \% \pm 0.86 \%)$ and total ash $(6.89 \% \pm 0.11 \%$ and $5.60 \% \pm 0.10 \%)$, respectively. However, Egyptian seeds have moisture content, protein, crude fat and total ash higher than Libyan seeds. Crude oil from Egyptian seeds had high refractive index and iodine value in comparison with crude oil from Libyan seeds. There were no remarkable differences between both seeds in acidity percent, unsaponifiable matters percent and saponification value. Linoleic, oleic and palmitic acids were the major fatty acid constituents in Egyptian Roselle seeds. Meanwhile linolenic, linoleic, oleic, stearic, palmitoleic and palmitic acids were the major fatty acid constituents in Libyan Roselle seeds. Crude oil from Egyptian seeds had higher percent of unsaturated fatty acids than crude oil from Libyan seeds. Unsaponifiable matters constituents for extracted oil from Egyptian seeds were free from n-pentacosane $\left(\mathrm{C}_{25}\right)$ and rich in $\mathrm{n}$-hexacosane $\left(\mathrm{C}_{26}\right)$. Oil from both seeds had the same content of Beta sito-sterol and stigma-sterol. Both seeds were rich in glutamic acid, aspartic acid, arginine and leucine. Libyan seeds were rich in essential amino acids in comparison with Egyptian seeds. Finally nutritional comparison of Roselle seeds variation depends on the variety, location and environmental conditions during cultivation. Roselle seeds are a good source for extraction of oil and protein. Protein from Roselle seeds could be used as a supplement material for poor food in lysine.
\end{abstract}

\section{Keywords}

Roselle Seed, Proximate Analysis, Oil Properties, Fatty Acids Profile, Unsaponifiable Matters, Amino Acids Profile 


\section{Introduction}

Seeds are however one of the cheapest food sources. Researchers have confirmed the nutritional usefulness of seeds [1] [2]. Interestingly, limited research has been carried out on exploitation and utilization of seeds as s potential alternative for human food source or even as food supplement. Roselle Hibiscus sabdriffa, which is a member of Malvaceae family, is believed to be native tropical African plants. Roselle is cultivated in many tropical and subtropical regions worldwide [3]. It is known by different synonyms and vernacular names such as Roselle [4] [5], Karkade [6] and Mesta [7]. Most studies were focused on the benefits of Roselle calyces rather than the seeds of the plant. The yield of seeds is reported to be $500-1000 \mathrm{Kg} \cdot \mathrm{acre}^{-1}\left(210-420 \mathrm{Kg}\right.$. Feddan $\left.{ }^{-1}\right)$ for an Indian cultivar [8]. There are published reports indicating that the seeds are eaten in some parts of Africa and also have been roasted as a coffee substitute material [9] [10]. Roselle seeds powder could also be used in cookies production as flour substitute till $20 \%$ to enhance the protein and dietary fibers contents [11].

In Egypt and Libya, seeds of Roselle plant are discarded as a by-product. Nutritional composition of Roselle seeds variation depends on the variety, location and environmental conditions where the seeds were cultivated [12]. Information from the literature indicated that Roselle whole seeds powder from other countries contained high amounts of protein, oil, carbohydrates [6] [7] [13] and dietary fiber [7]. Therefore, the study aims to evaluate the nutritional composition of Roselle seeds grown in Libya and Egypt and make comparison between chemical composition of Roselle seeds grown in Egypt and Libya. To achieve this purpose, whole chemical composition, fatty acids profile, amino acids profile, extracted oil properties and unsaponifiable matters were determined.

\section{Materials and Methods}

\subsection{Materials}

Two kilograms of each Roselle seeds from Libya and Egypt were sun dried, ground, sieved, through mesh screen, packed in polyethylene bags and stored in a deep freezer at $-20^{\circ} \mathrm{C}$ until analysis. Moisture content was determined directly after grounding and sieving before storage.

\subsection{Methods}

\subsubsection{Oil Extraction}

Oil was extracted by soaking the prepared seeds in petroleum ether $\left(40^{\circ} \mathrm{C}-60^{\circ} \mathrm{C}\right)$. The ratio of solvent to crushed seeds was 3:1. The crushed seeds soaked in solvent for 24 hours with shaking. Miscella (mixed oil with solvent) was removed from seeds by filtration through wattman filter paper No. 1 . The soaking was repeated three times. Solvent was removed from collected miscella by using of rotary evaporator at $40^{\circ} \mathrm{C}$ under vacuum. Oil was stored in dark bottle in deep freezer at $-20^{\circ} \mathrm{C}$ until analysis.

\subsubsection{Proximate Chemical Composition Analysis}

Moisture content of seeds powder was determined using air-oven method. Ash content was determined by incinerating at $550^{\circ} \mathrm{C}$ until constant weight was achieved. Total nitrogen and protein content were determined based on kjeldahl method using the conversion factor of 6.25. Lipids were determined by using soxhelt method. All of the above determinations were carried out based on methods as mentioned previously in A.O.A.C. [14] except the carbohydrate content (nitrogen free extract) which were determined by difference.

\subsubsection{Crude Oil Properties}

Refractive index, specific gravity, acidity, saponification value, iodine value, peroxidase value, Thiobarbituric acid (T.B.A) value and unsaponifiable matters were determined according to the methods described in A.O.C.S. [15].

\subsubsection{Fatty Acid Composition}

\section{(1) Separation of Fatty Acid}

Fatty acids were separated and change to methyl esters according to the methods described by [16]. The lipid samples were saponified over night with ethanolic $\mathrm{KOH} \mathrm{(20 \% )} \mathrm{at} \mathrm{room} \mathrm{temperature.} \mathrm{The} \mathrm{fatty} \mathrm{acids} \mathrm{were} \mathrm{free}$ from their potassium salts by acidification with hydrochloric acid $(5 \mathrm{~N})$, followed by extraction with ether or (pt. 
ether $40^{\circ} \mathrm{C}-60^{\circ} \mathrm{C}$ ). The ether extract was washed three times with distilled water then dried over anhydrous sodium sulfate, and filtered off.

\section{(2) Preparation of Diazomethane}

Diazomethane was prepared from methylamine hydrochloride as reported by [16] as follows:

Methylamine solution $(100 \mathrm{ml})$ was placed in stoppered $500 \mathrm{ml}$ flask and concentrated hydrochloric acid (78 $\mathrm{ml}$ ) and water added to bring the total weight to $250 \mathrm{~g}$. Urea $(150 \mathrm{~g})$ was introduced and mixture was boiled gently under reflux for $200 \mathrm{~min}$ and vigorously for $15 \mathrm{~min}$, the solution was cooled to room temperature, then sodium nitrite $(55 \mathrm{~g})$ was added at $0^{\circ} \mathrm{C}$.

A mixture of $300 \mathrm{~g}$ crushed ice and $50 \mathrm{~g}$ concentrated sulfuric acid was prepared in $1500 \mathrm{ml}$ beaker surrounded by bath of ice and salt. Cold methyl urea-nitrite solution was added slowly with mechanical stirring at such rate, that the temperature did not rise above $0^{\circ} \mathrm{C}$. The crystalline nitrosomethyl urea was filtered at once then drained well and dried in vacuum desiccator. Aqueous potassium hydroxide solution $(60 \mathrm{ml}, 50 \% \mathrm{w} / \mathrm{w})$ and ether $(200 \mathrm{ml})$ were placed in $500 \mathrm{ml}$ round bottomed flask. The mixture was cooled to $5^{\circ} \mathrm{C}$, then nitrosomethyl urea $(20.6 \mathrm{~g})$ and ether $(80 \mathrm{ml})$ were added. The ethereal layer was separated using separating funnel and dried over pellets of potassium hydroxide for 2 - $3 \mathrm{~h}$.

\section{(3) Identification and Determination of Fatty Acid by Gas Liquid Chromatography (GLC)}

Fatty acids were identified and determined by GLC according to the method described by [17]. The methyl ester of fatty acids obtained from oil of samples and standard materials were analyzed with a Pye Unicam Series 304 gas chromatography equipped with dual flam ionization detector and dual channel recorder. The separation of fatty acid methyl esters was conducted using a coiled glass column $(1.5 \mathrm{~m} \times 4 \mathrm{~mm})$ packed with Diatomite (100 - 120 mesh) and coated with $10 \%$ polyethylene glycol adipate (PEGA). The column oven temperature was programmed at $8^{\circ} \mathrm{C} / \mathrm{min}$ from $70^{\circ} \mathrm{C}$ to $190^{\circ} \mathrm{C}$, then isothermally at $190^{\circ} \mathrm{C}$ min with nitrogen at $30^{\circ} \mathrm{C} \mathrm{ml} / \mathrm{min}$.

\subsubsection{Unsaponifiable Matters}

The unsaponifiable matters were fractionated by using GLC according to the method described by [17]. The unsaponifiables were fractionated on a coiled glass column $(2.8 \mathrm{~m} \times 4 \mathrm{~mm})$ packed with Diatomite $(100-120$ mesh) and coated with $3 \% \mathrm{OV}-17$. The oven temperature was programmed at $10^{\circ} \mathrm{C} / \mathrm{min}$ from $70^{\circ} \mathrm{C}$ then isothermally at $270^{\circ} \mathrm{C}$ for $25 \mathrm{~min}$ and nitrogen flow rate was $30 \mathrm{ml} / \mathrm{min}$. Detector, injector temperatures and hydrogen, air flow rates were generally $300^{\circ} \mathrm{C}, 280^{\circ} \mathrm{C}$ and $33 \mathrm{ml}, 330 \mathrm{ml} / \mathrm{min}$, respectively. Peak identification was performed by comparison the retention time (RT) of each compound with those of standard materials. The linear relationship between log retention times of the standard hydrocarbons and number of carbon atoms of these compounds was used characterize the unavailable authentic hydrocarbons. Peak area was measured by using a computing integrator (PU4810, Philips).

\subsubsection{Amino Acid Profile}

The Amino acids profile was determined according to the method described by Cohen et al. [18] by using HPLC.

\subsubsection{Statistical Analysis}

Proximate analysis and crude oil properties were expressed as mean of three replicates \pm standard deviation according to the method described by Steel et al. [19].

\section{Results and Discussion}

\subsection{Proximate Analysis}

Results in Table 1 showed the proximate analysis of Egyptian and Libyan Roselle seeds. Results indicated that both whole seeds powder contained high amounts of crude oil, protein, total ash, water soluble and insoluble ash and nitrogen free extract [12] [13] [20]-[28]. The results of carbohydrates for both seeds (as nitrogen free extract) were in a good agreement with that mentioned by [28] [29]. The moisture content in both seeds was low which indicate the possibility of long shelf-life stability during storage in factories of oil production [21]. Results also indicated that Egyptian seeds have moisture, crude oil, protein, total ash, and water soluble and insoluble ash higher than Libyan seeds. These differences may be due to the differences in location and environmental conditions where seeds were cultivated [12]. 
Table 1. Chemical composition of Egyptian and Libyan Roselle seeds ${ }^{1}$.

\begin{tabular}{|c|c|c|}
\hline Components (\%) & Egyptian Seed $^{3}$ & Libyan Seed $^{3}$ \\
\hline Moisture & $9.25 \pm 0.35$ & $5.32 \pm 0.39$ \\
\hline Crude Fat & $21.60 \pm 0.66$ & $16.94 \pm 0.86$ \\
\hline Protein & $31.02 \pm 0.93$ & $28.67 \pm 0.45$ \\
\hline Total Ash & $6.89 \pm 0.11$ & $5.60 \pm 0.10$ \\
\hline - Soluble Ash & $2.29 \pm 0.04$ & $1.62 \pm 0.04$ \\
\hline - Insoluble Ash & $4.60 \pm 0.11$ & $2.98 \pm 0.08$ \\
\hline Carbohydrates $^{2}$ & $36.37 \pm 2.02$ & $43.47 \pm 1.98$ \\
\hline
\end{tabular}

${ }^{1}$ Light read seeds; ${ }^{2}$ Nitrogen Free Extract; ${ }^{3}$ Values are expressed as mean \pm SD of three replicates.

It could be noticed that seeds contained high amounts of crude oil and protein than cotton seeds which used in Egypt for oil production. We can conclude that Roselle seeds consider as a good and economic source for healthy edible oil and protein production [21]. In the other hand, the high content of ash indicated that seeds are a good source of minerals [7].

\subsection{Properties of Crude Roselle Seeds Oil}

Results in Table 2 showed some physical and chemical properties of crude Roselle seeds oil from Egyptian and Libyan seeds. There is no remarkable difference between Egyptian and Libyan seeds in acidity percent, saponification value, unsaponifiable matters percent, peroxide value and thiobarbituric (T.B.A) value. Results for specific gravity and acidity percent are in a good agreement with that reported in literature [21] [25] [30]. Crude oil from Egyptian seeds had refractive index more than oil from Libyan seed; meanwhile oil from Libyan seeds had higher density than oil from Egyptian seed. On other hand iodine value for oil from Egyptian seeds was $115 \pm$ 2.57; this value was high in comparison with iodine value for oil from Libyan seeds being 93.7 \pm 2.04 . Results for iodine value, saponification value, acidity percent and refractive index are in a good agreement with that mentioned by [21] [31]. In other hand, the unsaponifiable matters were low in comparison with results in [21] [25] [32]. It could be noticed that oil from Libyan seeds might be more stable against oxidative rancidity because it had low iodine value. Roselle seeds oil properties were not significantly different than those of corn oil, therefore Roselle seeds oil could be classified as semi-dry oil. Chemical composition and lipid fractions of Roselle seeds oil were similar to corn oil. As resulted, Roselle seeds oil might provide a new source of edible oil and confirmed [31].

\subsection{Fatty Acid Composition}

Results in Table 3 indicated that linoleic, oleic and palmitic acids were the major fatty acid constituents in Egyptian Roselle seeds being 38.17\%, 33.31\% and 18.15\% respectively [13] [21] [31] [32]. Meanwhile linolenic, linoleic, oleic, stearic, palmitoleic and palmitic acids were the major fatty acid constituents in Libyan Roselle seeds being 18.7\%, 17.5\%, 16.5\%, 15.97\%, 13.39\% and 12.7\% respectively [21] [25] [31]-[33]. A high content of unsaturated fatty acids constituents were $75.57 \%$ and $66.09 \%$ for Egyptian and Libyan Roselle seeds respectively.

The ratio of unsaturated to saturated fatty acids for Egyptian Roselle seeds was 3:1 the results are in a good agreement with that reported by [8] [21] [25] [31]-[33]. In contrast the ratio of unsaturated to saturated fatty acids for Libyan Roselle seeds was 2:1 the results are in a good agreement with that reported in literature [13] [20]. Decreasing unsaturated fatty acids in Libyan seeds and increasing its content of stearic acid could explain why crude oil of Libyan Roselle seeds had higher density and lower refractive index than crude oil from Egyptian Roselle seeds. Also it explains why crude oil from Libyan seeds had lower iodine value than crude oil from Egyptian Roselle seeds. Results for properties and fatty acids indicated that Roselle oil had similar properties to cotton seeds oil [8]. Finally there is a limitation in published data on Roselle seeds oil. 
Table 2. Properties of crude Roselle seeds oil.

\begin{tabular}{ccc}
\hline Properties & Egyptian Seed $^{* *}$ & Libyan Seed $^{* *}$ \\
\hline Refractive Index & $1.4777 \pm 0.0005$ & $1.4675 \pm 0.0005$ \\
Specific Gravity & $0.8995 \pm 0.0006$ & $0.9199 \pm 0.0049$ \\
Acidity (\%) & $0.67 \pm 0.028$ & $0.68 \pm 0.02$ \\
Unsaponifiable Matters (\%) & $0.81 \pm 0.02$ & $0.80 \pm 0.03$ \\
Saponification Value & $197 \pm 3.0$ & $197.93 \pm 2.09$ \\
Iodine Value & $115 \pm 2.57$ & $93.70 \pm 2.04$ \\
Peroxide Value & $6.51 \pm 1.54$ & $7.51 \pm 1.6$ \\
T.B.A Value & $1.04 \pm 0.03$ & $1.04 \pm 0.03$ \\
\hline
\end{tabular}

${ }^{*}$ As oleic acid; ${ }^{* *}$ Values are expressed as mean $\pm \mathrm{SD}$ of three replicates.

Table 3. Fatty acid composition of Roselle seeds.

\begin{tabular}{ccc}
\hline Fatty Acid & Egyptian Seeds (\%) & Libyan Seeds (\%) \\
\hline Myristic Acid (C14:0) & 2.19 & 5.24 \\
Palmitic Acid (C16:0) & 18.15 & 12.70 \\
Palmitoleic Acid (C16:1) & 2.00 & 13.39 \\
Stearic Acid (C18:0) & 4.09 & 15.97 \\
Oleic Acid (C18:1) & 33.31 & 16.50 \\
Linoleic Acid (C18:2) & 38.17 & 17.50 \\
Linolenic Acid (C18:3) & 2.09 & 18.70 \\
US:S Ratio & $3: 1$ & $2: 1$ \\
\hline
\end{tabular}

\subsection{Unsaponifiable Matters}

Results for unsaponifiable matters constituents in crude oil from Egyptian and Libyan seeds indicated that both seeds have the same constituents and percentage, results are given in Table 4.

Except that oil from Egyptian seeds was free from n-pentacosane $\left(\mathrm{C}_{25}\right)$ and had high percent of n-hexacosane $\left(\mathrm{C}_{26}\right)$ in comparison with oil from Libyan seeds. Hydrocarbons n-triacontane (C30), n-hentriacontane (C31), n-tetracosane (C24), n-tricosane (C23) and stigma sterols were the major unsaponifiable matters constituents in crude Roselle oil from both Egyptian and Libyan seeds. Crude oil from both seeds is considered as vegetable oil was rich in phytosterols [32]. Roselle seeds oil considers healthy oil because it contains high percent of phytosterols and free from cholesterol. Finally there are not enough studies on unsaponifiable matters of Roselle seeds oil especially for food applications.

\subsection{Amino Acids}

Data in Table 5 show the amino acid profile of Egyptian and Libyan Roselle seeds. Eighteen amino acids were detected in Roselle seeds powder [27]. Both seeds were rich in glutamic acid, aspartic acid, arginine and leucine [34]. Other essential amino acids are comparable to referenced protein [32] [35]. Egyptian Roselle seeds had higher percent of threonine, leucine, phenylalanine, lysine than Libyan seeds. Meanwhile Libyan seeds had higher percent of valine, isoleucine, tyrosine, histidine, tryptophan and glycine than Egyptian seeds. Essential to non-essential amino acid ratio was 0.7730 and 0.6636 for Libyan and Egyptian seeds respectively. Essential to total amino acid ratio was 0.4360 and 0.3989 for Libyan and Egyptian seeds respectively. Protein from Egyptian seeds contained amount of threonine and leucine more than that of FAO referenced protein. Meanwhile, valine, isoleucine and phenylalanine were lower than that of FAO referenced protein. Lysine was slightly lower than 
Table 4. Chemical composition of unsaponifiable matters of Roselle seeds oil.

\begin{tabular}{|c|c|c|}
\hline Components & Egyptian Seeds (\%) & Libyan Seeds (\%) \\
\hline n-undecane $\left(C_{11}\right)$ & 1.35 & 1.35 \\
\hline n-dodecane $\left(\mathrm{C}_{12}\right)$ & 2.35 & 2.35 \\
\hline n-tridecane $\left(\mathrm{C}_{13}\right)$ & 1.13 & 1.13 \\
\hline n-tetradecane $\left(C_{14}\right)$ & 2.51 & 2.51 \\
\hline n-pentadecane $\left(\mathrm{C}_{15}\right)$ & 1.98 & 1.98 \\
\hline n-hexadecane $\left(C_{16}\right)$ & 2.13 & 2.13 \\
\hline n-heptadecane $\left(\mathrm{C}_{17}\right)$ & 2.46 & 2.46 \\
\hline n-octadecane $\left(\mathrm{C}_{18}\right)$ & 1.67 & 1.67 \\
\hline n-nonadecane $\left(C_{19}\right)$ & 2.36 & 2.36 \\
\hline n-eicosane $\left(C_{20}\right)$ & 2.20 & 2.20 \\
\hline n-heneicosane $\left(C_{21}\right)$ & 3.28 & 3.28 \\
\hline n-docosane $\left(C_{22}\right)$ & 1.62 & 1.62 \\
\hline n-tricosane $\left(C_{23}\right)$ & 4.59 & 4.59 \\
\hline n-tetracosane $\left(C_{24}\right)$ & 5.74 & 5.74 \\
\hline n-pentacosane $\left(C_{25}\right)$ & - & 1.45 \\
\hline n-hexacosane $\left(C_{26}\right)$ & 3.11 & 1.66 \\
\hline n-heptacosane $\left(C_{27}\right)$ & 1.48 & 1.48 \\
\hline n-octacosane $\left(C_{28}\right)$ & 2.23 & 2.23 \\
\hline n-triacontane $\left(C_{30}\right)$ & 21.48 & 21.00 \\
\hline n-hentriacontane $\left(C_{31}\right)$ & 21.49 & 21.97 \\
\hline n-dotriacontane $\left(\mathrm{C}_{32}\right)$ & 2.02 & 2.02 \\
\hline Cholesterol & - & - \\
\hline Stigmasterol & 4.21 & 4.21 \\
\hline Beta-sito-sterol & 1.62 & 1.62 \\
\hline
\end{tabular}

Table 5. Amino acid profiles of Egyptian and Libyan Roselle seeds powder.

\begin{tabular}{cccc}
\hline Amino Acids & Egyptian Seeds \% & Libyan Seeds \% & FAO/WHO \\
\hline Essential Amino Acids & & & \\
Threonine & 4.86 & 2.64 & 4.0 \\
Valine & 3.26 & 5.33 & 5.0 \\
Methionine & 1.13 & 0.71 & 3.5 \\
Isoleucine & 3.24 & 4.65 & 4.0 \\
Leucine & 7.32 & 6.93 & 7.0 \\
Tyrosine & 3.64 & 6.31 & \\
Phenylalanine & 5.09 & 4.77 & 6.0 \\
Lysine & 5.37 & 3.02 & 5.5 \\
\hline
\end{tabular}




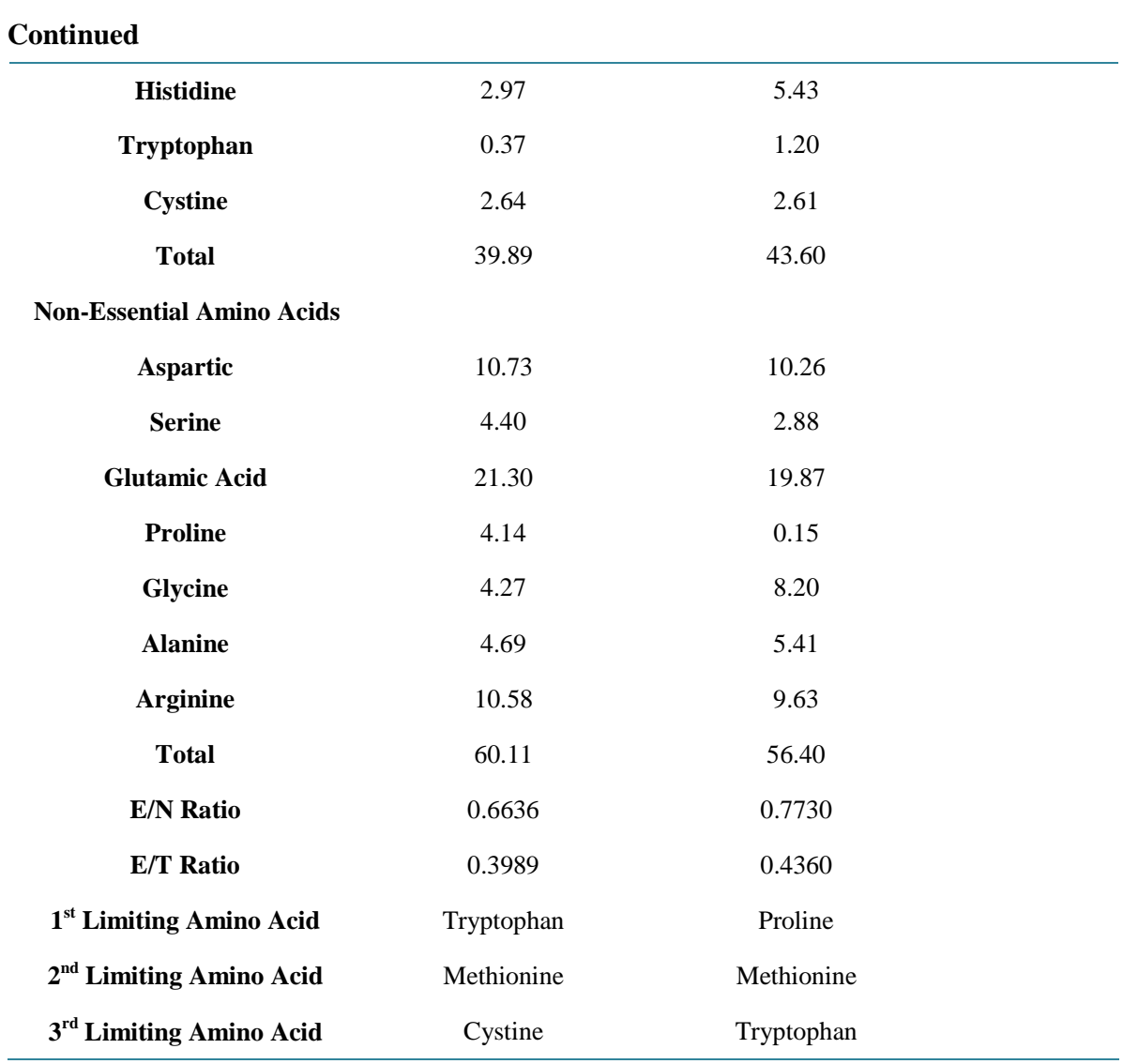

that of the FAO reference protein [36]. Libyan seeds protein contained amount of valine, isoleucine more than that of FAO referenced protein. In contrast threonine, phenylalanine and lysine were lower than that of FAO referenced protein. Leucine from Libyan seeds was slightly lower than that of FAO referenced protein. The content of both seeds for methionine was low in comparison with that of FAO referenced protein [36]. Finally it could be noticed that Libyan seeds was rich in essential amino acid in comparison with Egyptian seeds. The limiting amino acids for Egyptian seeds were tryptophan, methionine and cystine as first, second and third limiting amino acid respectively [27]. In contrast proline, methionine and tryptophan were limiting amino acids for Libyan seeds. The differences between Egyptian and Libyan Roselle seeds may be related to the variations in cultivated region [34].

\section{Conclusion}

Roselle seeds are a good source for extraction of protein and oil. Roselle seeds vary in nutritional composition depending on the location and environmental conditions during cultivation. Protein from Roselle seeds could be used as a supplement agent of food mixture for poor lysine sources. Roselle seeds still need further investigation for oil properties and protein quality for human nutrition practices.

\section{References}

[1] Barampama, Z. and Simard, R.E. (1993) Nutrient Composition, Protein Quality and Anti-Nutritional Factors of Some Varieties of Dry Beam (Phaseolus vulgaris) Grown in Burundi. Food Chemistry, 47, 159-167. http://dx.doi.org/10.1016/0308-8146(93)90238-B

[2] Saleh Al-Jassir, M. (1992) Chemical Composition and Microflora of Black Cumin (Nigella sativa L.) Seeds Growing in Saudi Arabia. Food Chemistry, 45, 239-242.

[3] Akanbi, W.B., Olaniyan, A.B., Togun, A.O., Hupeju, A.E.O. and Alaniran, A.O. (2009) The Effect of Organic and Inorganic Fertilizer on Growth, Calyx Yield and Quality of Roselle (Hibiscus sabdriffa L.). American-Eurasian Journal of Sustainable Agriculture, 3, 652-657. 
[4] Tsai, P.J., McIntosh, J., Pearce, P., Camden, B. and Jordan, B.R. (2002) Anthocyanin and Antioxidant Capacity in Roselle (Hibiscus sabdariffa L.) Extract. Food Research International, 35, 351-356. http://dx.doi.org/10.1016/S0963-9969(01)00129-6

[5] Chewonarin, T., Kinouchi, T., Katuoka, K., Arimachi, H., Kuwahara, T. and Initkekumnuen, U. (1999) Effect of Roselle (Hibiscus sabdariffa Linn.), a Thai Medicinal Plant, on the Mutagenicity of Various Unknown Mutagens in Salmonella typhimurium and Formation of Aberrant Crypt Foci Induced by the Colon Carcinogens Azoxymethane and 2-Amino-1-methyl-6-phenylimidazo[4,5-b]pyridine in F344 Rates. Food and chemical Toxicology, 37, 591-601. http://dx.doi.org/10.1016/S0278-6915(99)00041-1

[6] Abu-Tarbouch, H.M., Ahmed, S.A.B. and Alkahtani, H.A. (1997) Some Nutritional Properties of Karkade (Hibiscus sabdariffa) Seeds Product. Cereal Chemistry, 74, 352-355. http://dx.doi.org/10.1094/CCHEM.1997.74.3.352

[7] Rao, P.U. (1996) Nutrient Composition and Biological Evaluation of Mesta (Hibiscus sabdariffa) Seeds. Plant Foods for Human Nutrition, 49, 27-34. http://dx.doi.org/10.1007/BF01092519

[8] Mohiuddin, M.M. and Zaidi, H.R. (1975) Composition and Characteristic of Hibiscus sabdriffa Seeds Oil. Fat, Soap and Cooling Materials, 77, 488-489.

[9] Morton, J. (1987) Roselle. In: Morton, J.F., Ed., Fruits of Warm Climates, Florida Flair Books, Miami, 281-286.

[10] Duke, J.A. (1983) Malvaceae Roselle. In: Handbook of Energy Crops, 345-369. https://www.hort.purdue.edu/newcrop/duke_energy/dukeindex.html

[11] Nyam, K., Leao, S., Tan, C. and Long, K. (2012) Functional Properties of Roselle (Hibiscus sabdriffa L.) Seeds and Its Application as Bakery Product. Journal of Food Science and Technology, 51, 3830-3837.

[12] Hainida, E., Amin, I., Normah, H., Mohd-Esa, N. and Anial, Z.A.B. (2008) Effects of Defatted Dried ROSELLE (Hibiscus sabdariffa L.) Seeds Powder on Lipid Profile of Hypercholesterolemia Rats. Journal of the Science of Food and Agriculture, 88, 1043-1050. http://dx.doi.org/10.1002/jsfa.3186

[13] El-Adawy, T.A. and Khalil, A.H. (1994) Characteristics of Roselle Seeds as a New Source of Protein and Lipid. Journal of Agricultural and Food Chemistry, 42, 1986-1900.

[14] AOAC (2000) Official Methods of Analysis of the Association of Official Analytical Chemists. 17th Edition, Washington DC.

[15] AOCS (2010) American Oil Chemists Society. Official Methods and Recommended Practices. American Oil Chemists Society, Champaign.

[16] Vogel, A.J. (1975) A Textbook of Practical Organic Chemistry. 3rd Edition, English Language Book Society and Longman Group Ltd., London, 969-971.

[17] Farag, R.S., Hallabo, S.A.S., Hewedi, F.M. and Basyony, A.E. (1986) Chemical Evaluation of Rapeseed. Fette, Seifen, Anstrichmittel, 88, 391-397. http://dx.doi.org/10.1002/lipi.19860881006

[18] Cohen, S.A., Mewyes, M. and Travin, T.L. (1989) The Pico-Tag Method: A Manual of Advanced Techniques for Amino Acid Analysis. Millipore, Billerica.

[19] Steel, R., Torrie, J. and Dickey, D. (1997) Principles and Procedures of Statistics: A Biometrical Approach. 3rd Edition, McGraw-Hill, New York.

[20] Shaheen, M.A., El-Nakhlawy, F.S. and Al-Shareef, R.A. (2012) Roselle (Hibiscus sabdriffa) Seeds as Unconventional Nutritional Source. African Journal of Biotechnology, 44, 9821-9824.

[21] Nzikou, J.M., Bouanga-Kalou, G., Matos, L., Ganongo-po, F.B., Mboungou-Mboussi, P.S., Moutoula, F.E., PanyooAkdow, E., Silou, T.H. and Desobry, S. (2011) Characteristics and Nutritional Evaluation of Seeds Oil from Roselle (Hibiscus sabdriffa L.) in Congo-Brazzaville. Current Research Journal of Biological Sciences, 3, 141-146.

[22] Parkouda, C., Diawara, B. and Ouoba, L.I.I. (2008) Technology and Physico-Chemical Characteristics of Bikalga, Alkaline Fermented Seeds of Hibiscus sabdriffa. African Journal of Biotechnology, 7, 916-922.

[23] Yagoub, A. and Mohammed, M.A. (2008) Fururndu, a Meat Substitute from Fermented Roselle (Hibiscus sabdriffa L.) Seed: Investigation on Amino Acids Composition, Protein Fractions, Minerals Content and HCl-Extractability of Microbial Growth. Pakistan Journal of Nutrition, 7, 352-358. http://dx.doi.org/10.3923/pjn.2008.352.358

[24] Yagoub, A.A., Mohammed, A.M. and Abu Baker, A.A. (2008) Effect of Soaking, Sprouting and Cooking on Chemical composition, Bioavailability of Minerals in Vitro Digestibility of Roselle (Hibiscus sabdriffa L.) Seed. Pakistan Journal of Nutrition, 7, 50-56. http://dx.doi.org/10.3923/pjn.2008.50.56

[25] Awad, A.M., Selim, K.A. and Abdel-Baki, M.R. (2008) Physico-Chemical and Oxidative Stability Characteristics of Roselle Seeds Oil as By-Product. Egypt Journal of Applied Science, 23, 247-257.

[26] Abu-Tarboush, M.H. (1995) Factors Affecting Protein Extractability of Defatted Karkade (Hibiscus sabdriffa) Seeds Flour. College of Foods and Agricultural Science. J. King Saud Univ. Agric. Sci., 7, 179-186.

[27] Al-Wandawi, H., Al-Shaikhly, K. and Abdul-Rahman, M. (1984) Roselle Seed: A New Protein Source. Journal of 
Agricultural and Food Chemistry, 32, 510-512. http://dx.doi.org/10.1021/jf00123a022

[28] Samy, M.S. (1980) Chemical and Nutritional Studies on Roselle Seeds (H. sabdriffa L.). Journal of Olea Science, 10, 32-38.

[29] Cissouma, A.I., Tounkara, F., Nikoo, M., Yang, N. and Xu, X. (2013) Physico-Chemical Properties and Antioxidant Activity of Roselle Seeds Extracts. Advance Journal of Food Science and Technology, 5, 1483-1489.

[30] Nakpong, P. and Wootthikanokkhan, S. (2010) Roselle (Hibiscus sabdriffa L.) Oil as an Alternative Feedstock for Biodiesel Production in Thailand. Fuel, 89, 1806-1811. http://dx.doi.org/10.1016/j.fuel.2009.11.040

[31] Atta, M.B. and Imaizumi, K. (2002) Some Characteristics of Crude Oil Extracted from Roselle (Hibiscus sabdriffa L.) Seeds Cultivated in Egypt. Journal of Oleo Science, 51, 457-461. http://dx.doi.org/10.5650/jos.51.457

[32] Mohamed, R., Fernandez, J., Pineda, M. and Aquilar, M. (2007) Roselle (Hibiscus sabdriffa) Seeds Oil Is a Rich Source of Gamma-Tocopherols. Journal of Food Science, 72, S207-S211. http://dx.doi.org/10.1111/j.1750-3841.2007.00285.x

[33] Fiad, S. (1991) Component Triacylglycerol of Six Seeds Oils of Malvaceae. Journal of the American Oil Chemists Society, 68, 23-25.

[34] Ismail, A., Emmy Hainida, K.I. and Nazri, H.S.A. (2008) Roselle (Hibiscus sabdriffa L.) Seed—Nutritional Composition, Protein Quality and Health Benefits. Global Science Books, Food, 2, 1-16.

[35] El Faki, A.E., Dirar, H.A., Collins, M.A. and Harper, D.B. (1991) Biochemical and Microbiology Investigation of Sigda_-A Sudanese Fermented Food Derived from Sesame Seeds Oil Cake. Journal of the Science of Food and Agriculture, 57, 351-365. http://dx.doi.org/10.1002/jsfa.2740570306

[36] FAO/WHO (1975) Energy and Protein Requirement. PAG Bulletin 5, PAG, New York, 30-35. 
Scientific Research Publishing (SCIRP) is one of the largest Open Access journal publishers. It is currently publishing more than 200 open access, online, peer-reviewed journals covering a wide range of academic disciplines. SCIRP serves the worldwide academic communities and contributes to the progress and application of science with its publication.

Other selected journals from SCIRP are listed as below. Submit your manuscript to us via either submit@scirp.org or Online Submission Portal.
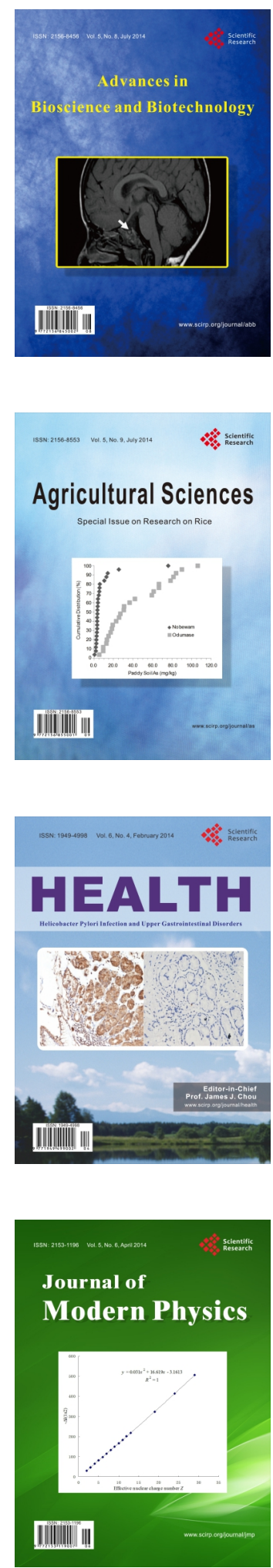
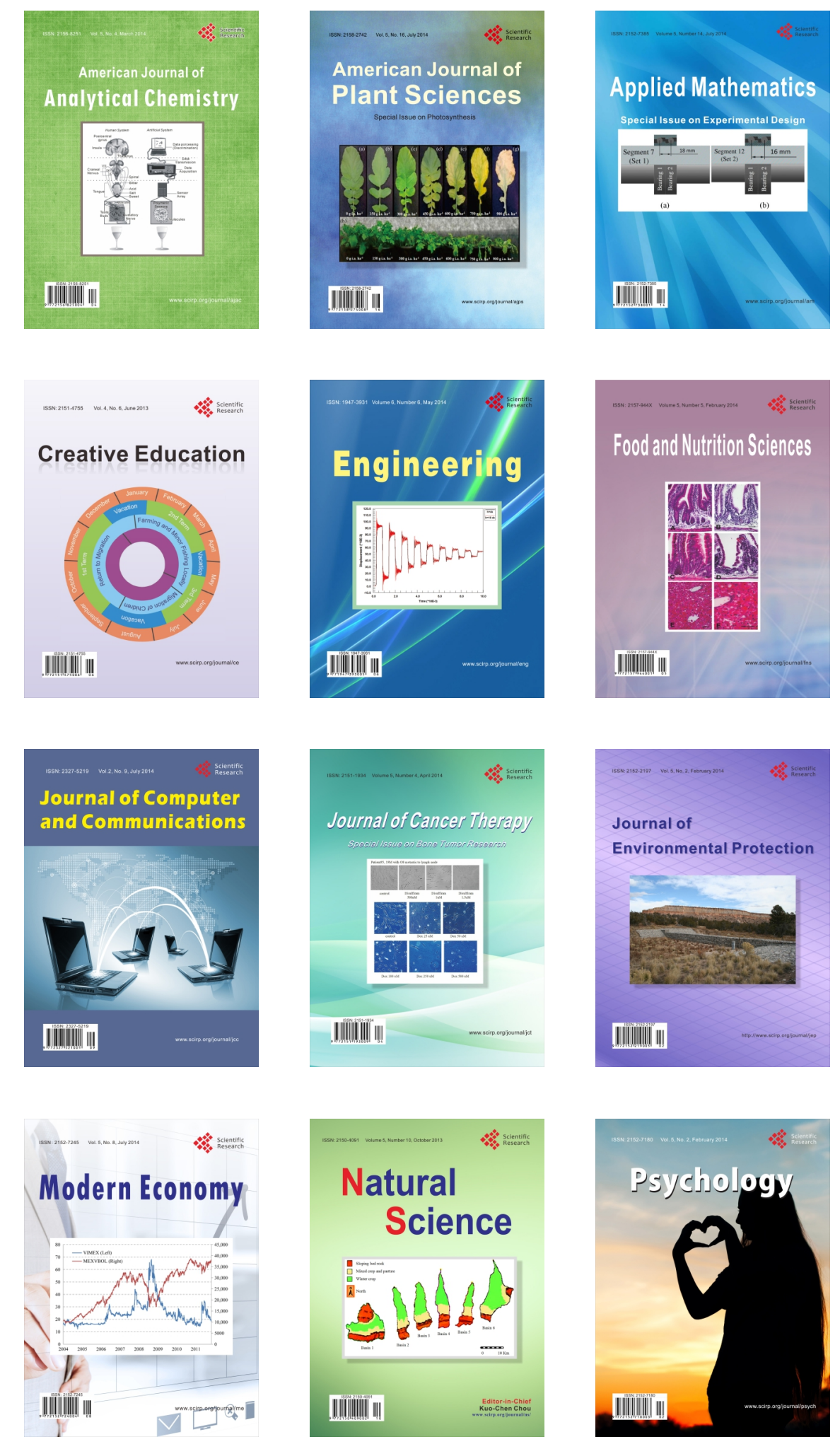